\title{
Introduction: metropolis and India
}

Whatever the precise nature of the shift in Britain's role from a trading to a colonial power in India, not in doubt was the dramatic increase in demand for knowledge of the nascent colony. After the decisive battle of Plassey, the various forms of knowledge production grew exponentially. In 1784 the Asiatic Society of Bengal was formed. In 1788 James Rennell published Memoir of a Map of Hindustan or the Moguls Empire. It was the first British work to chart details of India's inland topography instead of maritime routes. Control over land-revenue management gave access to important technical details and Mughal sources of information. ${ }^{1}$ Travelogues and associated historical-philosophical surveys appeared, and proved popular. $^{2}$

It was at this moment, states Bernard Cohn, that metropolis and colony were brought into a unitary epistemological field. In introducing this idea, he has argued elegantly that the eighteenth-century European state established its authority by codifying and controlling representation of the relationship between the past and the present. ${ }^{3}$ The accumulation of vast amounts of information on finance, trade, health, crime and industry served this end. In Britain this cultural project was integral to the country's emergence as a colonial power, and since India was potentially the most important colony, the consolidation of the state brought the two countries into a relationship of mutual reciprocity:

It is not just that the personnel who governed Indian [sic] were British, but the projects of state building in both countries - documentation, legitimation, classification, and bounding, and the institutions therewith - often reflected theories, experiences, and practices worked out originally in India and then applied to Great Britain, as well as vice versa. Many aspects of metropolitan documentation were first developed in India. ${ }^{4}$

This process reached its zenith with the establishment of the nineteenth-century Raj. India was the laboratory for the Enlightenment project 


\section{THE OTHER EMPIRE}

that provided the pillars of reason. Many branches of the natural sciences were catalysed by the demands attendant on colonial expansion. ${ }^{5}$ India was also the test bed for methods of domestic government, while British public schools manufactured the governing elite for service in India. ${ }^{6}$ All this was set in motion, however, toward the close of the previous century, and lubricated by theories on the nature of Indian culture and society. Government was predicated on knowledge of the cultural forms of India forms that came to be transformed by the very process that sought to understand them. Again reciprocity obtained. 'Culture was imbricated both in the means and the ends of colonial conquest', argues Nicholas Dirks, 'and culture was invented in relationship to a variety of internal colonialisms.' Colonial culture reached back to the metropolis, to emerge in and inform domestic concerns. ${ }^{7}$

Metropolitan histories were profoundly influenced by events in India. It is difficult to explain, for example, the emergence of racialized conceptions of the poor in the second half of the nineteenth century without acknowledging the impact of notions of Indian castes and tribes, and of the seismic rupture created by the 1857 uprising. Such questions command much of what appears in the following chapters, but as a prelude it is necessary to examine briefly the emergence of the 'unitary field' in the latter stages of the eighteenth century.

Prior to the establishment of the Raj, connections between India and England were evident in travel writings and imaginative literature. A cursory glance at these does suggest that travelogues entered into the expansive domain of poetry and drama. ${ }^{8}$ Initially, perceptions of foreign lands and peoples derived from the mythical tales of Alexander, Marco Polo and Mandeville, ${ }^{9}$ but with the flowering of literary culture and the accumulation of contemporary travel accounts the place occupied by the exotic changed. At the most basic level, contemporary authors drew upon such mythical tales as a means of embellishing references to the foreign and the exotic. Milton's Paradise Lost, Shakespeare's Macbeth and The Tempest, Spenser's The Faerie Queene, Locke's Essay Concerning Human Understanding, Marlowe's Tamburlaine the Great, Thomas Moore's Lalla Rookh and Donne's The Embassy all reveal knowledge of travel accounts and geographies. But these accounts were not used merely as a ready taxonomy of exotic characters and phenomena; they shaped geographical and ethnological imaginations. The trangressiveness of the exotic in Shakespeare, for example, reveals a struggle to contain the ambiguous or liminal in a commonwealth being forged by the age of discovery. Indeed, it is impossible fully to appreciate these imaginations in Shakespeare, unless they are located contradictorily between the new consciousness struggling for superiority over the ancient, and the abiding lure of the fabled past. ${ }^{10}$

Andrew Hadfield's more introspective study of the impact of travel 
writing in the early modern period reveals how such works reflected on problems within the English body politic at a time of change. ${ }^{11}$ Because of the uncertain status shared by writers of prose fiction, dramatists and travellers, they chose consciously to disguise what were often radical critiques of the existing order using conveniently remote locations. Thus representations of foreign lands and peoples were used allegorically to address a host of pressing domestic issues around national identity, the constitution, the distribution of power and individual liberty. More generally, the seventeenth century witnessed a critical stage in the transition from narratives of pilgrimage and exploration to those of the secular traveller equipped with the new epistemology of scientific and rational inquiry. ${ }^{12}$ Integral to this project was a heightened obligation to establish the historicity and authenticity of travel accounts, primarily through original documentation and reputable eyewitness testimony. Those relying on medieval notions of the fabulous and monstrous were increasingly discredited by sceptical narrative voices committed to rendering a truth securely based on empirical sources and methodologies.

Mutualities between early travelogues and popular writings on London are less evident. Even though the first body of popular, secular literature emerged toward the end of the sixteenth century, that is, at the moment when the first travellers to India were recording their observations, the writings of Robert Green, Thomas Dekker and Thomas Nashe articulated a distinct and jealously guarded urban mentality. In contrast to interpretations provided by the moral authority of church, court and City, the transitional metropolitan scene found expression in an eclectic range of destabilizing moral and verbal conventions. ${ }^{13}$ In a host of hugely popular plays, pamphlets and ballads, London became a dangerous, labyrinthine landscape, the interpretation of which was possible only for figures occupying that liminal space between moral and criminal authority, who descended into the world of deception, fraud and temptation, subsequently to emerge and recount their experiences. There is a sense here that the metropolis provided all that an ambitious and inquisitive traveller could need. It is instructive that Nashe's The Unfortunate Traveller (1594) - one of the very few examples of crossing generic boundaries - was a hostile attack on the putative merits of (European) travel. ${ }^{14}$ In certain respects, travellers to India shared the same sense of journey into a strange and unknown world, but their interpretative authority owed nothing to the transgressive rationale of the pamphleteers, and proved singularly incapable of expressing Indian culture except through the perspective of a mercantile elite in pursuit of commercial gain. Even the rabelaisian buffoonery of Thomas Coriat, struggling to define the generic boundaries of English travel writing, revealed little beyond this.

The narrative forms and the epistemological transformation evident in 
travel accounts were a formative influence on eighteenth-century literature. It was not just that personalized accounts of (self) discovery provided the narrative structure of the first novels, but also that the combination of extreme scepticism and naïve empiricism constituted the self-conscious critical theory necessary for their emergence as a genre. ${ }^{15}$ With Defoe's Robinson Crusoe and Swift's Gulliver's Travels the boundaries between travelogue and fiction - always fluid - seemed to vanish. And in form and content there are repeated references to travellers' accounts in Defoe's Moll Flanders, Richardson's The Negotiations of Sir Thomas Roe in his Embassy to the Ottoman Porte, Fielding's Tom Jones, Sterne's Tobias Smollet and Goldsmith's Citizen of the World.

The relationship at this time between forms within the burgeoning literary culture of the metropolis is complex. For there were powerful countervailing tendencies. In representing London's increasing dominance of national and imperial ambitions, the eighteenth-century metropolitan bourgeoisie 'contributed to a new form of imperial, august urbanism that in turn redefined the bourgeois ideals and practices of the merchant class' ${ }^{16}{ }^{16}$ Through this process the values and styles of a metropolitan elite were consolidated and came to exert greater hegemonic control over the English ruling class as a whole. Tensions evident in the previous century between elite and popular literature gradually dissipated. The radical subversiveness of satire declined, to be replaced by hack writings seemingly incapable of transcending the tired, formulaic narratives of tricks-of-the-town travelogues. ${ }^{17}$ Lawrence Manley captures well the consequences of this shift:

The national literature did not become homogeneous, not were its elements identical - a world of difference still separated Dryden's Miscellanies from Tom D'Urfey's Wit and Mirth, or Ned Ward's London Spy from Pope's Dunciad. But the general interorientation of various urbane decora, at least from within the institution, made this difference negotiable in ways that the differences between, say, Astrophil and Stella and Greene's cony-catching pamphlets were not. ${ }^{18}$

This negotiability was effectively realized with the creation of a unitary field in the second half of the century, for the bringing together of metropolis and colony was predicated on a convergence of different forms of knowledge. Recent scholarship has suggested that the European imaginary of the late eighteenth and early nineteenth centuries was profoundly influenced by a resurgent interest in the East, not all of which was dictated by colonial imperatives. ${ }^{19}$ To deal adequately with this complex issue we would thus need to investigate the extent to which India entered into Enlightenment and Romantic thought. Cohn's emphasis, however, is on the 'investigative modalities' of the project of the British to classify, 
categorize and hence control the new empire in India, that is, the 'procedures by which appropriate knowledge is gathered, its ordering and classification, and then how it is transformed into usable forms such as published reports, statistical returns, histories, gazetteers, legal codes and encyclopaedias' ${ }^{2}{ }^{20}$ There were six interrelated and overlapping modalities:

1 The historiographic had ontological efficacy in rationalizing and thereby facilitating British rule. It comprised a number of strands. Historical inquiries were undertaken into customs and local histories which came to form the basis of land tenure, assessment and revenue collection. Indian civilization itself was explored in historical perspective, usually within a teleological framework that validated British rule. And British rule was the subject of popular histories of specific events such as the Black Hole of Calcutta. Although the most complex, this modality was pervasive, and generally seen as the most valuable.

2 The observational/travel involved particular itineraries that incorporated familiar locations and encounters. Accounts of these travels drew upon tropes made familiar by earlier travelogues, although their precise representation reflected changing socio-economic contexts.

3 The survey embraced a wide range of practices including, most significantly, the mapping of India, but also the collection and systematic classification of flora, fauna, ethnology and architecture.

4 The enumerative was driven by the perceived need to collect and classify data. Over time, those on prices, customs, duties and coinage were supplemented by more ethnographic concerns, realized in the massive compilation of information on caste, religion and occupation. After 1857 this totalizing project came to fruition in the series of censuses.

5 The museological was a by-product of land surveys and settlement proceedings. It identified and recorded archaeological sites, and collected artefacts, manuscripts and oral histories which were later housed in museums and national collections. This project helped to define India's past.

6 The surveillance refers to the means by which the British gathered information on those groups and practices that were perceived to threaten the social order. Thugs, dacoits, religious mendicants, and the various tribes thought beyond civilizing influence were singled out for attention. In the process, many tribes and castes were criminalized. ${ }^{21}$

If India did indeed become known to the British, these modalities provided the means. The whole immense project to gather, classify, categorize and order information brought India within a European imagination. Partial, incomplete and replete with contradiction this project may have been, but it possessed sufficient power to help secure and maintain British dominance. This power derived from its sheer ambition; few features of 


\section{THE OTHER EMPIRE}

Indian society were left untouched by the hands of surveyors, census enumerators, photographers and cartographers. What underpinned the project was an empiricism that, by reducing colonial knowledge to factual statements about observable reality, made possible the bringing together onto a common epistemological terrain not only of different forms of evidence (gazetteers, statistical returns, topographical surveys, oral testimony), ${ }^{22}$ but also of different disciplines (anthropology, history, sociology, science), and of different spaces (Indian regions, London). More important, however, I believe that the knowledge field was constituted by and cohered around an articulating principle. This principle was progress. At that moment in the late eighteenth century when India became subject to the knowledgeable gaze of the British state, belief in the idea of progress took shape. This belief structured the ways in which both metropolis and colony came to be understood.

Through this process - complex, multivalent and pervasive - diverse peoples within the ascendant commercial empire were constructed as primitive and hence incorporated hierarchically into the European human order. This had profound consequences for the ways in which these subject peoples were represented throughout the nineteenth century. Differences would remain on whether savagery represented a prelapsarian state of innocence, or a state of degeneration into which peoples had fallen from a previously higher one, but the important point was that savages were so because they had not been subject to the law of progress. It was in this way that colonial subjects, black slaves and the urban poor were culturally constituted by the doctrine of progressivism, and their continued exploitation justified. The seeming paradox was that this unified project was launched at that moment when elements within Enlightenment humanism encouraged recognition of the longevity of non-European civilizations, and of the barbarity of slavery. As Christopher Bayly explains:

\footnotetext{
Ironically, the growing and orchestrated contempt for Asian, African and even European subordinates was derived in part from the very same humanitarian drives which saw the abolition of the slave trade and the beginning of the moves for the emancipation of slaves. It was morally necessary to bring slaves back from social death into civil society. But if so, the hierarchy of civil society must be closely defined both through institutions and by an ideology which derived from the idea that cultures attained 'civilisation' by stages of moral awakening and material endeavour. The 'discovery' of the urban poor and the criminal classes in Britain were part of a very similar project and undertaken by the same civil and religious agencies. ${ }^{23}$
}

Identification of the uncivilized was thus made possible in part by the use of an older rhetoric of heathenism, savagery and paganism, and these were to continue as powerful motives late into the nineteenth century. As we shall see, in the age of imperial modernity race came to define the bounda- 


\section{INTRODUCTION: METROPOLIS AND INDIA}

ries of progress, as subject peoples were perceived increasingly in terms of rigidified racial hierarchies.

In the chapters that follow I explore aspects of this process. To address the field in its entirety is well beyond the limits of a single volume. It would have been legitimate, for example, to examine mutualities between metropolis and colony in the development of education, public health, governance, municipal reform, policing and town planning. Instead I intend to focus on what was perceived to be the most threatening antitheses to progress, namely, the metropolitan poor and colonial peoples. In terms of their chronologies, rhetoric, narratives and agencies there were distinct homologies between the discursive appropriation of the poor and of colonial subjects during the long nineteenth century, suggesting that the London poor were an object of imperial and not merely domestic concern. These homologies were to be found in the diverse array of reports, inquiries, minutes and surveys that resulted from the quotidian processes of imperial rule. More significantly, however, they were evident in the published accounts that reached a wider audience, and so entered into popular consciousness. Among these, the writings of travellers and evangelicals were by far the most influential. Before considering this literature I wish to explore the rise of the idea of progress and how it structured British thought on the place of non-European peoples in the new world order.

\section{Notes}

1 C.A. Bayly, Empire and Information. Intelligence Gathering and Social Communication in India, 1780-1870, Cambridge, Cambridge University Press, 1996, p. 49.

2 Among these might be mentioned William Robertson's An Historical disquisition concerning the Knowledge which the Ancients had of India (1791) and Abbe Raynal's Philosophical History of the East and West Indies (1776). The latter was among the most borrowed travel books from Bristol Library over the period 1773-84 (Peter J. Marshall and Gwynn Williams, The Great Map of Mankind. British Perceptions of the World in the Age of Enlightenment, London, Dent, 1982, p. 57).

3 Bernard S. Cohn, Colonialism and its Forms of Knowledge. The British in India, Princeton, Princeton University Press, 1996, pp. 3-5. I have taken a small liberty with Cohn's arguments here; he talks of the desire of the state to represent the past, while I believe it was more concerned to locate the present in relation to the past.

4 Ibid., pp. 4-5.

5 Nicholas B. Dirks, 'Introduction: colonialism and culture', in Nicholas B. Dirks (ed.), Colonialism and Culture, Ann Arbor, University of Michigan Press, 1992, p. 6.

6 See also Eric Stokes, The English Utilitarians and India, Oxford, Oxford University Press, 1959.

7 Dirks, 'Introduction: colonialism and culture', p. 4.

8 Balachandra Rajan, Under Western Eyes. India from Milton to Macaulay, Durham, Duke University Press, 1999, is an interesting reconnaissance into this neglected field.

9 Donald F. Lach, Asia in the Making of Europe. Vol. II. A Century of Wonder, Chicago, University of Chicago Press, 1993, p. 381. Lach does tend to understate the impact of travel literature on satire and poetry in Tudor England.

10 For a sophisticated study of the influence of cartographical poetics on seventeenth- 


\section{THE OTHER EMPIRE}

century theatre see John Gillies, Shakespeare and the Geography of Difference, Cambridge, Cambridge University Press, 1994, while Margaret Hodgen's Early Anthropology in the Sixteenth and Seventeenth Centuries, Philadelphia, University of Pennsylvania Press, 1964, remains the best account of the impact of the new ethnology.

11 Andrew Hadfield, Literature, Travel, and Colonial Writing in the English Renaissance, Oxford, Clarendon Press, 1998.

12 This whole question is explored with exemplary rigour by Michael McKeon, The Origins of the English Novel, 1600-1740, London, Radius, 1988, pp. 100-17.

13 Lawrence Manley, Literature and Culture in Early Modern London, Cambridge, Cambridge University Press, 1995, p. 301. Manley's fine survey of this literary culture makes no reference to travel writings.

14 Hadfield, Literature, Travel, and Colonial Writing, pp. 192-6.

15 McKeon, The Origins of the English Novel, p. 118.

16 Manley, Literature and Culture in Early Modern London, p. 516.

17 See below, pp. 47-9.

18 Manley, Literature and Culture in Early Modern London, p. 520.

19 Raymond Schwab, The Oriental Renaissance. Europe's Rediscovery of India and the East, 1680-1880, Guildford, Columbia University Press, 1984; Nigel Leask, British Romantic Writers and the East. Anxieties of Empire, Cambridge, Cambridge University Press, 1992; Alan Richardson and Sonia Hofkosh, Romanticism, Race and Imperial Culture, 1780-1834, Bloomington, Indiana University Press, 1996; Tim Fulford and Peter Kitson (eds), Romanticism and Colonialism. Writing and Empire, 1780 1830, Cambridge, Cambridge University Press, 1998.

20 Cohn, Colonialism and its Forms of Knowledge, p. 5.

21 Ibid., pp. 5-11. To this list I am tempted to add the 'intelligence modality' through which extensive networks of Indian informers were created to provide military, social and political information. This added to the storehouse of information on Indian peoples and cultures, and was critical to the success of the Raj (Bayly, Empire and Information).

22 David Ludden, 'Orientalist empiricism: transformations of colonial knowledge', in Carol A. Breckenridge and Peter van der Veer (eds), Orientalism and the Postcolonial Predicament. Perspectives on South Asia, Philadelphia, University of Pennsylvania Press, 1993.

23 C.A. Bayly, Imperial Meridian. The British Empire and the World, 1780-1830, London, Longman, 1989, p. 7. 